\title{
Analyzing the Crystal Structure of Alveolar Bone and its Impact on the Rate of Tooth Movement
}

\author{
Mohsen Shirazi, ${ }^{1}$ Armin Soudi, ${ }^{2}$ Pedram Baghaeian, ${ }^{2}$ and Yasamin Farajzadeh Jalali3, ${ }^{3}$ \\ ${ }^{1}$ DDS, MS, Professor, Department of Orthodontics, Tehran University of Medical Sciences, Tehran, IR Iran \\ ${ }^{2}$ DDS, Postgraduate Student of Orthodontics, Department of Orthodontics, Tehran University of Medical Sciences, Tehran, IR Iran \\ ${ }^{3}$ Assistant Professor, Department of Orthodontics, School of Dentistry, Ilam University of Medical Sciences, Ilam, IR Iran \\ "Corresponding author: Yasamin Farajzadeh Jalali , Assistant Professor, Department of Orthodontics, School of Dentistry, Ilam University of Medical Sciences, Ilam, Iran. Tel: \\ +98-2188351162, E-mail: yassi.jalali@gmail.com
}

Received 2016 June 19; Accepted 2016 September 23.

\begin{abstract}
Background: The aim of this study was to investigate the crystal structure of mineral part in the Compact and Cancellous bones in different areas of alveolar bones.

Methods: In this study, 7 alveolar bone samples were prepared from buccal and distal plates of the jaws of three patients, and 4 samples from Cortical and Cancellous bone of two other patients' palate. After converting all the samples into powder, the samples were examined by using the X-RD method. Diffractogram of 1-7 samples were compared with each other and Diffractogram of 8-11 samples also were compared with each other too.

Results: Comparing two corresponding points in the jaws the crystallinity degree in the mandible is higher than the maxilla. In comparison of two corresponding points in the maxilla and mandible degree of crystallinity and the crystalline hydroxyapatite on the right has been more than on the left. The amount of crystalline hydroxyapatite phase in females is more than males and crystallinity degree of this phase in males is more than females, and in younger people, the hydroxyapatite crystalline phase is more than others and crystallinity of this phase in older subjects is higher than others.

Conclusions: Tooth movement, despite the influence of the same forces, is faster on left side than the right side and is faster on maxilla than mandible. Tooth movement is faster in younger people than in older subjects.
\end{abstract}

Keywords: Hydroxyapatite, X-Ray Diffraction, Alveolar Bone, Orthodontic Tooth Movement

\section{Background}

Orthodontic tooth movement is a complicated process, requiring changes in the gingiva, periodontal ligament, root cementum, and alveolar bone with their difference in cell population and remodeling activity (1). Several factors, such as age, drug consumption, diet, several systemic conditions, and other intrinsic genetic factors, have been shown to influence the rate of tooth movement (2, 3). Clinically, differences in the rate of tooth movement even in the same patient can be observed. In certain cases, the role of neighboring touching teeth or occlusal interferences by antagonist teeth seem to influence the amount of the tooth displacement (4). Bridges et al. showed the bone that is less mineralized at the outset should be more easily remodeled, which could be expressed by a shorter delay period in the tooth movement cycle due to more rapid resorption. It is also clear that the mineral density of a complex site like alveolar process can also be affected by several systemic and anatomic factors (5).

$85 \%$ of bone mineral sector is in the form of calcium phosphate, $10 \%$ as calcium carbonate and \% 5.1 in the form of phosphate and magnesium (6). Studies by X- ray diffraction (X-RD) have shown that calcium and phosphorus form apatite-like crystals with possible formula of $\mathrm{ca}_{10}\left(\mathrm{po}_{4}\right) 6 \mathrm{ca}(\mathrm{OH})_{2}$ or $3 \mathrm{ca}_{3}\left(\mathrm{po}_{4}\right)_{2} \mathrm{ca}(\mathrm{OH})_{2}(7,8)$. X-RD relies on the dual wave/particle nature of X-rays to obtain information about the structure of crystalline materials. A primary use of the technique is the identification and characterization of compounds based on their diffraction pattern. The dominant effect that occurs when an incident beam of monochromatic X-rays interacts with a target material is scattering of those X-rays from atoms within the target material. In materials with regular structure, the scattered X-rays undergo constructive and destructive interference. The directions of possible diffractions depend on the size and shape of the unit cell of the material. The intensities of the diffracted waves depend on the kind and arrangement of atoms in the crystal structure. When a powder with randomly oriented crystallites is placed in an X-ray beam, the beam will see all possible interatomic planes. If the experimental angle is systematically changed, all possible diffraction peaks from the powder will be detected (9).

Crystalline hydroxyapatite ions are hydrated, and a

Copyright (C) 2016, Iranian Journal of Orthodontics. This is an open-access article distributed under the terms of the Creative Commons Attribution-NonCommercial 4.0 International License (http://creativecommons.org/licenses/by-nc/4.0/) which permits copy and redistribute the material just in noncommercial usages, provided the original work is properly cited. 
layer of water and ions is formed around crystals which is called hydration shell, and provides ion exchange between crystals and fluids (10). In a crystalline structure, every single cell is similar to other units of cell of that structure in terms of size, shape, orientation and location of atoms, the same, and so, with a complete description of a cell unit, all the body's structure will be described (11).

In response to orthodontic loading the first bone was formed usually is the woven type that is weak, disorganized, and poorly mineralized. During the two phase of mineralization woven bone remodeled to lamellar bone that is a strong, highly organized, and well mineralized tissue. A portion of the mineral component (hydroxyl apatite) is deposited by osteoblasts during primary mineralization. Secondary mineralization, which completes the mineral component, is related directly to its mineral content (11).

The aim of this study was to evaluate the crystal structure of bone mineral sector in different area of the alveolar process and comparison of the rate of tooth movement in these areas.

\section{Methods}

11 bone samples were selected from palate and alveolar of three 20-year-old female patients and 20 to 35-years-old male patients from referring to the Department of Surgery, School of Dentistry, Tehran University, who had referred in order to remove their canine teeth or wisdom teeth, and were prepared. The samples were as follows:

- Samples 1 and 2 of the left and right of mandible of a 20-year-old male.

-Sample 3 of the left of the mandible and samples 4 and 5 of the right of maxilla and mandible of a 20 -year-old female.

- Samples 6 and 7 of the left and right of mandible of 20-year-old female.

- Sample 8 of compact bone, sample 9 of cancellous bone on the right of palate of a 35-year-old male.

- Sample 10 of compact bone and sample 11 of cancellous bone on the right of 20-year-old female's palate.

All patients were healthy, and did not have any discomfort or lesion in the jaws. After surgery, parts with dimensions of $7 \times 4 \mathrm{~mm}$ of bone were prepared, and immediately placed in $10 \%$ formalin solution. To prepare, samples for each patient simultaneously were placed in separate dishes for half an hour at a temperature of $1100^{\circ} \mathrm{C}$ on the Krupp dental EK 18/18 furnace, and then slowly cooled and removed from the furnace respectively. Because of the small size of the samples, they converted into powder by hand using agate mortar and pestle made of silica, and then were examined by X-RD and using Diffractometer (Philips PW 1730/10) under conditions of kv: 45, time: 2 seconds, $\mathrm{mA}: 40,2 \theta>4^{\circ}$ (Figure 1 ).

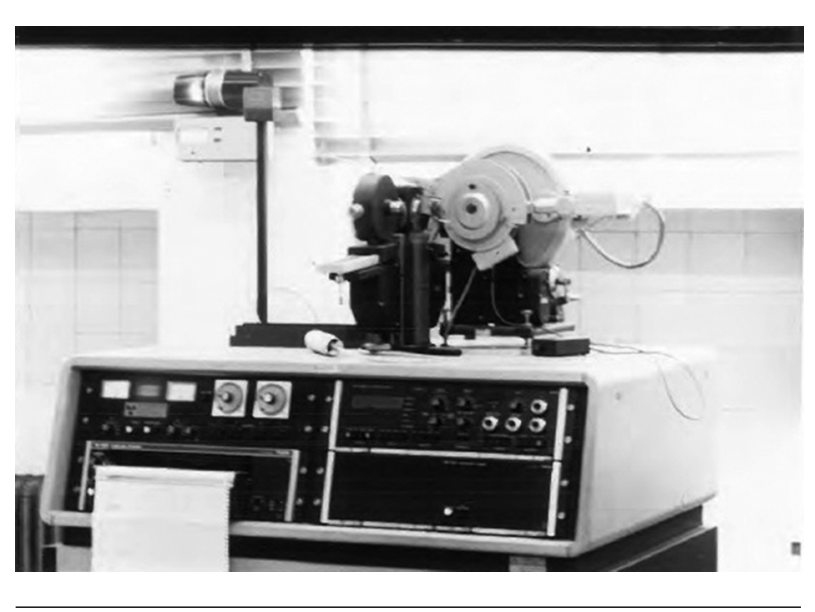

Figure 1. X-Ray Diffractometer (Philips PW 1730/10)

In study of diffractograms, 3 factors were considered and compared: existing phases, the degree of crystallinity in the hydroxyapatite phase, and the hydroxyapatite phase.

\section{Results}

Existing Phases: According to Tables 1 and 2, we can see that, in all cases, a hydroxyapatite crystalline phase (phase A) is available. In some cases, in addition to this phase, additional phases can also be seen. In samples 3 and 4, there is additional crystalline phase $B$ which the peaks of its indicators are in areas with angles $\theta_{2}=11.92$ and $\theta_{2}=24.5$. Third phase $C$ with peaks of indicator in areas of $\theta_{2}=3.58$ and $\theta_{2}$ $=34.7$ can be seen in the sample 7 , but there isn't in other cases.

The degree of crystallinity in the hydroxyapatite phase: The crystallization degree of a phase is determined due to being sharp or flat of its peak on the diffractogram, and indicates the accuracy of the crystal structure of the object. Namely, with increasing the accuracy of the crystal structure the degree of crystallinity increases. In Tables 1 and 2 , comparison of the crystallinity degree of hydroxyapatite in the samples studied is presented.

The hydroxyapatite phase: Due to the similarity of conditions for preparation of the samples and conditions of $\mathrm{X}$ $\mathrm{RD}$, the difference in height of the peak in diffractogram indicates the difference in the amount of crystalline hydroxyapatite in the relevant samples. Less crystalline hydroxyapatite in a sample may be due to less amount of the mineral sector, or more amount of amorphous hydroxyapatite 
Table 1. Comparison of Cancellous bone with Trabecular Bone Samples

\begin{tabular}{|c|c|c|c|}
\hline Samples & $\begin{array}{l}\text { The Degree of } \\
\text { Crystallinity in } \\
\text { the Common } \\
\text { Phase }\end{array}$ & $\begin{array}{l}\text { Height of the } \\
\text { Peak in } 2 \theta= \\
31.9^{\circ} \text { (Amount of } \\
\text { Crystalline } \\
\text { Hydroxyapatite) }\end{array}$ & Additional Phase \\
\hline 8,9 & $\begin{array}{c}\text { Sample of No. } 8 \text { is } \\
\text { more }\end{array}$ & $\begin{array}{l}\text { Sample of No. } 8 \text { is } \\
\text { more }\end{array}$ & $\begin{array}{c}\text { Phase B in sample } \\
\text { No.8 }\end{array}$ \\
\hline 10,11 & $\begin{array}{c}\text { Sample of No. } 10 \text { is } \\
\text { more }\end{array}$ & $\begin{array}{l}\text { Sample of No. } 10 \text { is } \\
\text { more }\end{array}$ & $\begin{array}{c}\text { Phase B in sample } \\
\text { No.10 }\end{array}$ \\
\hline 8,10 & $\begin{array}{l}\text { Sample of No. } 8 \text { is } \\
\text { more }\end{array}$ & $\begin{array}{l}\text { Sample of No. } 10 \text { is } \\
\text { more }\end{array}$ & $\begin{array}{c}\text { Phase B in both of } \\
\text { samples }\end{array}$ \\
\hline 9,11 & $\begin{array}{l}\text { Sample of No. } 9 \text { is } \\
\text { more }\end{array}$ & $\begin{array}{l}\text { Sample of No. } 9 \text { is } \\
\text { more }\end{array}$ & - \\
\hline
\end{tabular}

or additional crystalline phases in the sample. The results of the comparison of diffractograms of the alveolar samples bone showed that, in all cases, comparison of two corresponding points in the jaws ( 1 and 4 ), ( 1 and 7 ), (5 and 4 ), ( 5 and 7 ), ( 2 and 6 ) and (3 and 6 ) the crystallinity degree of phase $\mathrm{A}$ in the mandible is more than the maxilla. In comparison of two corresponding points in the maxilla (4 and 6), (7 and 6), degree of crystallinity and the crystalline hydroxyapatite on the right has been more than on the left.

In comparison of two corresponding points in the mandible ( 1 and 3 ), ( 5 and 3 ), ( 1 and 2 ) and (5 and 2 ), degree of crystallinity and the crystalline hydroxyapatite on the right has been more than on the left. If the samples are sampled from the same places ( 1 and 5), (2 and 3), we can consider the impact of gender. The amount of crystalline hydroxyapatite phase in females is more than males and crystallinity degree of this phase in males is more than females, and in the same condition in younger people, the hydroxyapatite crystalline phase is more than others and crystallinity degree of this phase in older subjects is higher than others. Another result was that there is the additional phase B ( $\alpha$-ca3 (PRO) 2 ) in both compact bone samples (10 and 8) but there isn't in any cancellous bone samples (9 and 11).

\section{Discussion}

In the present study X-RD was used to provide most definitive structural information about bone mineral sector. X-RD showed three kind of composition based on their diffraction. Hydroxyapatite crystalline phase was available in all cases and two additional phases were observed in some samples. The result of this study showed that the hydroxyapatite phase in females was more than males and crystallinity degree of this phase in males more than females, because the presence of additional crystalline phases is the reason for the lack of crystallinity degree of
Table 2. Comparison of Alveolar Bone Samples in the Maxilla and Mandible

\begin{tabular}{|c|c|c|c|}
\hline Additional Phase & $\begin{array}{c}\text { Height of the } \\
\text { Peak in } 2 \theta=31.9^{\circ} \\
\text { (Amount of } \\
\text { Crystalline } \\
\text { Hydroxyapatite) }\end{array}$ & $\begin{array}{l}\text { The Degree of } \\
\text { Crystallinity in } \\
\text { the Common } \\
\text { Phase }\end{array}$ & Samples \\
\hline- & $\begin{array}{l}\text { Sample of No. } 1 \text { is } \\
\text { more }\end{array}$ & $\begin{array}{l}\text { Sample of No. } 1 \text { is } \\
\text { more }\end{array}$ & 1,2 \\
\hline $\begin{array}{l}\text { phase B in } \\
\text { sample No.3 }\end{array}$ & $\begin{array}{l}\text { Sample of No. } 1 \text { is } \\
\text { more }\end{array}$ & $\begin{array}{l}\text { Sample of No. } 1 \text { is } \\
\text { more }\end{array}$ & 1,3 \\
\hline $\begin{array}{l}\text { phase B in } \\
\text { sample No.5 }\end{array}$ & $\begin{array}{l}\text { Sample of No. } 5 \text { is } \\
\text { more }\end{array}$ & $\begin{array}{l}\text { Sample of No. } 5 \text { is } \\
\text { more }\end{array}$ & 5,2 \\
\hline $\begin{array}{l}\text { phase B in both } \\
\text { of samples }\end{array}$ & $\begin{array}{l}\text { Sample of No. } 5 \text { is } \\
\text { more }\end{array}$ & $\begin{array}{l}\text { Sample of No. } 5 \text { is } \\
\text { more }\end{array}$ & 5,3 \\
\hline $\begin{array}{l}\text { phase B in both } \\
\text { of samples }\end{array}$ & $\begin{array}{l}\text { Sample of No. } 4 \text { is } \\
\text { more }\end{array}$ & $\begin{array}{l}\text { Sample of No. } 4 \text { is } \\
\text { more }\end{array}$ & 4,6 \\
\hline $\begin{array}{l}\text { Phase B in } \\
\text { sample No.6 } \\
\text { Phase C in } \\
\text { sample No.7 }\end{array}$ & $\begin{array}{l}\text { Sample of No. } 7 \text { is } \\
\text { more }\end{array}$ & $\begin{array}{l}\text { Sample of No. } 7 \text { is } \\
\text { more }\end{array}$ & 7,6 \\
\hline $\begin{array}{l}\text { phase B in } \\
\text { sample No.4 }\end{array}$ & $\begin{array}{l}\text { Sample of No. } 1 \text { is } \\
\text { more }\end{array}$ & $\begin{array}{l}\text { Sample of No. } 1 \text { is } \\
\text { more }\end{array}$ & 1,4 \\
\hline $\begin{array}{l}\text { phase B in } \\
\text { sample No.7 }\end{array}$ & $\begin{array}{l}\text { Sample of No. } 1 \text { is } \\
\text { more }\end{array}$ & $\begin{array}{l}\text { Sample of No. } 1 \text { is } \\
\text { more }\end{array}$ & 1,7 \\
\hline $\begin{array}{l}\text { phase B in both } \\
\text { of samples }\end{array}$ & $\begin{array}{l}\text { Sample of No. } 5 \text { is } \\
\text { more }\end{array}$ & $\begin{array}{l}\text { Sample of No. } 5 \text { is } \\
\text { more }\end{array}$ & 5,4 \\
\hline $\begin{array}{l}\text { Phase B in } \\
\text { sample No.5 } \\
\text { Phase C in } \\
\text { sample No.7 }\end{array}$ & $\begin{array}{l}\text { Sample of No. } 5 \text { is } \\
\text { more }\end{array}$ & $\begin{array}{l}\text { Sample of No. } 5 \text { is } \\
\text { more }\end{array}$ & 5,7 \\
\hline $\begin{array}{l}\text { phase B in } \\
\text { sample No.6 }\end{array}$ & $\begin{array}{l}\text { Sample of No. } 2 \text { is } \\
\text { more }\end{array}$ & $\begin{array}{l}\text { Sample of No. } 2 \text { is } \\
\text { more }\end{array}$ & 2,6 \\
\hline $\begin{array}{l}\text { phase B in both } \\
\text { of samples }\end{array}$ & $\begin{array}{l}\text { Sample of No. } 3 \text { is } \\
\text { more }\end{array}$ & $\begin{array}{l}\text { Sample of No. } 3 \text { is } \\
\text { more }\end{array}$ & 3,6 \\
\hline $\begin{array}{l}\text { phase B in } \\
\text { sample No.5 }\end{array}$ & $\begin{array}{l}\text { Sample of No. } 5 \text { is } \\
\text { more }\end{array}$ & $\begin{array}{l}\text { Sample of No. } 1 \text { is } \\
\text { more }\end{array}$ & 1,5 \\
\hline $\begin{array}{l}\text { phase B in } \\
\text { sample No.3 }\end{array}$ & $\begin{array}{l}\text { Sample of No. } 3 \text { is } \\
\text { more }\end{array}$ & $\begin{array}{c}\text { Sample of No. } 2 \text { is } \\
\text { more }\end{array}$ & 2,3 \\
\hline $\begin{array}{l}\text { Phase B in } \\
\text { sample No.4 } \\
\text { Phase C in } \\
\text { sample No.7 }\end{array}$ & $\begin{array}{l}\text { Sample of No. } 7 \text { is } \\
\text { more }\end{array}$ & $\begin{array}{l}\text { Sample of No. } 4 \text { is } \\
\text { more }\end{array}$ & 4,7 \\
\hline
\end{tabular}

hydroxyapatite crystallization phase in the samples of females. It may be associated with genetic variations or may be associated with circulating hormones that play an important role in bone turn over and bone metabolism (1). Since additional phase doesn't have any relationship with gender, but is related to the nature of the bone tissue, it seems that, in the samples of females, the amount of compact bones and therefore additional crystalline phases is more than others. Our results are consistent with other researchers have previously stated $(6,10)$.

In the same condition in younger people, the hydroxyapatite crystalline phase is more than others and crys- 
tallinity degree of this phase in older subjects is higher than others. Keeting et al. showed the same teeth in growing children move about twice as fast as they move in adults and they suggested the rate of tooth movement in inversely related to bone density and the volume of bone resorbed (12).

The result of the present study showed the crystallinity degree of hydroxyapatite in the mandible is more than the maxilla and also the degree of crystallinity and the crystalline hydroxyapatite on the right side has been more than on the left side. This difference may be due to using one side more than the other for function such as mastication. Repetitive loading generates a specific response, which is associated with decreasing in remodeling (13).

This difference in mineral sector of alveolar bone can affect the rate of tooth movement. Goldie and King suggested that in the rodent model, teeth were shown to move faster in animals that had an induced decrease in bone density (14) and also a similar study in beagle dogs showed that tooth movement was slower in denser dentoalveolar complexes (15). If so, when the two bone samples are subjected to the same forces, a sample has more organic content and therefore fewer minerals, will respond to this force better and faster.

Thus, according to the results, it can be expected that, tooth movement despite the influence of the same forces in the same form and size of the root on the left side is done faster than the right side and on the maxilla is done faster than the mandible.

A histomorphometric evaluation of alveolar bone turnover between the maxilla and the mandible during experimental tooth movement in dogs has defined the differential response of the jaws to tooth movement (16). From a clinical perspective in consistent with our result, maxillary bone is more responsive orthodontic loading because it is primarily composed of trabecular bone (17).

\subsection{Conclusion}

1. The degree of crystallinity and the amount of crystalline hydroxyapatite in the mandible is more than the maxilla and on the right side is more than the left side.

2. The crystallinity degree of crystalline hydroxyapatite in compact bone is more than the cancellous bone.

3. In compact bone, there is an additional crystalline phase that can't be seen in cancellous bone.
4. Tooth movement despite the influence of the same forces in the same form and size of the root on the left side is done faster than the right side and on the maxilla is done faster than the mandible.

\section{References}

1. Graber LW, Vanarsdall Jr RL, Vig KW. Orthodontics: current principles and techniques. Elsevier Health Sciences; 2011.

2. Dudic A, Giannopoulou C, Kiliaridis S. Factors related to the rate of orthodontically induced tooth movement. Am J Orthod Dentofacial Orthop. 2013;143(5):616-21. doi: 10.1016/j.ajodo.2012.12.009. [PubMed: 23631963].

3. Raisz LG. Pathogenesis of osteoporosis: concepts, conflicts, and prospects. J Clin Invest. 2005;115(12):3318-25. doi: 10.1172/JCI27071. [PubMed: 16322775].

4. Guo Y. Rate of orthodontically induced tooth movement. Am J Orthod Dentofacial Orthop. 2013;144(2):165. doi: 10.1016/j.ajodo.2013.06.004. [PubMed: 23910193].

5. Bridges T, King G, Mohammed A. The effect of age on tooth movement and mineral density in the alveolar tissues of the rat. Am JOrthod Dentofacial Orthop. 1988;93(3):245-50. [PubMed: 3422781].

6. Pawlicki R, Knychalska-Karwan Z, Karwan T.X-ray microanalysis of the rat bone. Folia Biologica. 1986;35(3-4):217-20.

7. Blumenthal NC, Betts F, Posner AS. Effect of carbonate and biological macromolecules on formation and properties of hydroxyapatite. CalcifTissue Res. 1975;18(2):81-90. [PubMed: 1148899].

8. Junqueira LC, Carneiro J. Basic histology text and atlas. London: McGraw Hill; 2005.

9. Moecher DP. Characterization and identification of mineral unknowns: A mineralogy term project. J Geosci Educ. 2004;52(1):5-9.

10. Enlow DHWB. Piezoelectricity. Alveolar bone. Handbook of facial growth. Saunderes; 2012.

11. Jain GC. Properties of electrical engineering materials. Harper \& Row; 1967.

12. Keeting PE, Scott RE, Colvard DS, Han IK, Spelsberg TC, Riggs BL. Lack of a direct effect of estrogen on proliferation and differentiation of normal human osteoblast-like cells. J Bone Miner Res. 1991;6(3):297-304. doi: 10.1002/jbmr.5650060312. [PubMed: 2035356].

13. Martin RB, Burr DB. Structure, function, and adaptation of compact bone. Raven Pr; 1989.

14. Goldie RS, King GJ. Root resorption and tooth movement in orthodontically treated, calcium-deficient, and lactating rats. Am J Orthod. 1984;85(5):424-30. [PubMed: 6586081].

15. Midgett RJ, Shaye R, Fruge JJ. The effect of altered bone metabolism on orthodontic tooth movement. Am J Orthod. 1981;80(3):256-62. [PubMed: 6945049].

16. Romain DR, Columbano-Green LM, Parfitt RG, Smythe RH, MacKenzie NG, Chapman CJ. Late replication studies and esterase D levels in a case of unbalanced X;autosome translocation, 46,X,t(X;13)(q27;q12).J Med Genet. 1988;25(10):716-8. [PubMed: 3225828].

17. Deguchi T, Takano-Yamamoto T, Yabuuchi T, Ando R, Roberts WE, Garetto LP. Histomorphometric evaluation of alveolar bone turnover between the maxilla and the mandible during experimental tooth movement in dogs. Am J Orthod Dentofacial Orthop. 2008;133(6):88997. doi:10.1016/j.ajodo.2006.12.013. [PubMed:18538254]. 